\title{
Dynamics and Sources of Expenditure Inequality in Bhutan: Theil and Blinder Oaxaca Decomposition Analysis
}

\section{Tobden $\mathrm{T}^{*}$}

Masters of Environmental and Resource Economics, National Statistics Bureau, Bhutan

\begin{abstract}
The distinct feature of Bhutan is its special attention to peace, prosperity and happiness for its people. This research focuses on the expenditure inequality for 2007 and 2012 using various measurements including Gini Coefficients, Theil Indices and Blinder-Oaxaca decomposition. The results show that "between" rather than "within" inequality is the major factor contributing to the overall inequality. Thus, reducing inequality within rural and urban areas, within districts and even among the men and women should be the focus in future endeavors for better equity in the society.
\end{abstract}

Keywords: Between inequality; Bhutan; Blinder-Oaxaca decomposition; Equity; Gini coefficients; Theil; Within equality

\section{Introduction}

Bhutan has a vision for peace, prosperity and happiness. Recognizing this vision, the Royal Government of Bhutan initiated the first FiveYear-Plan (FYP) in 1961 [1]. Promoting the welfare of the people and operationalizing the concept of the Gross National Happiness (GNH) has been enshrined in the Constitution of the Kingdom of Bhutan and the Vision 2020. All development policies have been aligned with the principle of reducing poverty and removing inequality [2]. The current 11th FYP has an objective to improve the welfare of the poor people, promote good governance, private sector development, promote culture and conserve the natural environment [3]. The unique development philosophy and socio economic developments are guided by Gross National Happiness (GNH).

Studies regarding poverty in Bhutan show that there is increasing inequality between urban and rural areas. Poverty Reduction Strategy Paper was developed by the government in 2004 as the part of its initiatives to fight against poverty. Priority needs were identified and Profiling of Poor were done [4]. Kidu (wellbeing) Foundation was launched in 2011 with an objective to assist vulnerable sections of the society. Landless people are given land. However, inequality has been growing and there is growing concern by the policymakers in the country. The Gini Index which was estimated at 0.35 in 2007 grew to 0.36 in 2012. The urban component increased from 0.32 in 2007 to 0.35 in 2012, while rural sector was recorded from 0.32 in 2007 to 0.34 in 2012 [5].

This paper complements the literature by investigating the dynamics in inequality for 2007 and 2012. In doing So, the study uses the household data to calculate a range of inequality measures including the Gini Coefficients, Theil Indices and Blinder-Oaxaca decomposition. The results show that "within" rather than "between" inequality is the major factor contributing to the overall inequality. Hence, this calls for the effort of the government to focus on this aspect of inequality in future initiatives to enhance equity in Bhutan.

The paper is organized as follows. Section 1 discusses background and related literature; Section 2 presents empirical method; and Section 3 the data used in the study. The results and discussions are presented in Section 4, and Section 5 concludes.

\section{Background and Related Literature}

Rapid economic development has transformed Bhutan significantly over the past few decades. The real GDP has doubled from Nu. 4,733 million in 1980 to $\mathrm{Nu}$. 7,476 million in 2015 [6]. The share of the agriculture sector in GDP has fallen from $56 \%$ in 1980 to $17 \%$ in 2015. As the economy undergoes rapid transformation, the inequality in Bhutan is likely to worsen.

The national poverty rate of Bhutan was recorded at 12 percent in 2012, a decrease from a high of 23.2 percent in 2007 [7]. The Gini Index which measures the inequality was also estimated at 0.36 in 2012 from 0.35 in 2007 based on expenditure. The Gini Index for urban was 0.32 in 2007 and 0.35 in 2012 while for rural was 0.32 in 2007 and 0.34 in 2012. This clearly indicates that inequality in Bhutan is becoming a pressing issue like any other countries in the world. While reducing the incidence of poverty is one side of the story, linking inequality to poverty reduction for a poor country like Bhutan may be necessary.

Analytical reports on poverty are published for public dissemination. The National Statistics Bureau conducts Bhutan Living Standard Survey (BLSS) every three to five years depending on the availability of the fund. While the reports cover comprehensive information on poverty, there are not much information regarding inequality other than the aggregate inequality figures. Thus, conducting deeper analysis on inequality is imperative as it depicts a broader picture on the welfare of the people. The literature shows that statistics on poverty focus only on the lower tail of the distribution, while inequality considers the whole distribution [8]. Therefore, having poverty statistics alone may not help the government in addressing poverty and inequality.

While many reports like Poverty Analysis Report of 2007; 2012 and Multi-Dimensional Poverty Index 2012 estimate the Gini Index at the national level, what remains unclear is the work on explaining how the urban rural expenditure disparity occurs and what contributes to the overall inequality. No decomposition studies are done to comprehend the determinants. The Multi-Dimensional Poverty Index Report of NSB

*Corresponding author: Tobden T, Masters of Environmental and Resource Economics, National Statistics Bureau, Bhutan, Tel: 0097577415125; E-mail: tobden1984@gmail.com

Received April 11, 2017; Accepted August 09, 2017; Published August 16, 2017

Citation: Tobden T (2017) Dynamics and Sources of Expenditure Inequality in Bhutan: Theil and Blinder Oaxaca Decomposition Analysis. Bus Eco J 8: 314. doi: 10.4172/2151-6219.1000314

Copyright: ( 2017 Tobden T. This is an open-access article distributed under the terms of the Creative Commons Attribution License, which permits unrestricted use, distribution, and reproduction in any medium, provided the original author and source are credited. 
talks more about poverty from the prospective of health, education and standard of living using Alkire Foster methodology, but even here the inequality has again been left unexplained [9].

Thus, not even a single national report covers the aspects of expenditure inequality. Understanding inequality, particularly how the between and within sector components have changed over the years, are important for guiding the policies and programs towards reducing national poverty and inequality.

\section{Empirical Methods}

Income and expenditure are two different measure of the standard of living. However, which one stands as the best measure has been a long subject of debate. For the case of developing countries, consumption could be preferred over income based on conceptual and practical considerations (World Bank). Income data in Bhutan are quite weak and even for the matter of national accounts estimates, expenditure data are considered reliable. Thus, expenditure inequality has been chosen over the income to measure inequality.

Expenditure inequality has been decomposed in various ways. The most widely used decomposition technique is decomposition by population subgroups. The Gini Coefficient, Theil Index and Regression based approach are some of the techniques used for decomposition.

Cowell and Jenkins [10] describe a range of decomposition techniques for inequality. They mention decomposition by factor sources and by population subgroup. The analysis by population subgroup provides information on the contribution to the overall inequality' by different population subgroups [11]. However, inequality disaggregation by population subgroups have been considered as concerning issue as it is subject to appropriate use of decomposition technique and the choice of the inequality measure [12].

Different decomposition methods provide different theoretical arguments and empirical justifications. For example, Gini decomposition has been considered as not capturing the upward and downward moment of the distribution [13]. The Gini coefficient is also not easily decomposable (Bourguignon) [14] and this has led to the infrequent use of the Gini coefficient in the decomposition analysis [15].

Each decomposition method has its own advantages and limitations. Decomposition techniques are the standard approach to examine the contribution to the overall inequality by within and between sector components [8]. However, according to Litchfield [8] caution must be taken as sensitive measures may behave in a perverse fashion. Nonetheless, in the absence of any other appropriate methods, decomposition methods and regression based techniques are considered as a valuable exercise.

Many studies on expenditure inequality are conducted based on the Theil decomposition. For example, an analysis on expenditure inequality in Indonesia using the household expenditure data of 1987, 1990 and 1993 by Akita et al. [16] uses Theil decomposition. Hayashi et al. [17] also use an alternative Theil decomposition and Blinder-Oaxaca decomposition besides the conventional Theil decomposition to study expenditure inequality in Indonesia.

Brewer and Wren-Lewis [18] uses regression based decomposition to establish the contributions of household characteristics of UK from 1978-2009. The inequality of elderly and young children with low income have found to converge with other over the years. The study on inequality in India by Cain et al. [19] has employed factor component analysis, and they find that the return to education accounts for the rise of inequality in urban areas.

The regression based decomposition technique has been applied to find the contribution to the overall inequality. The approach has the advantage of controlling the endogeneity problem by using a continuous variable [20]. Unlike other decomposition techniques, which require a set of separate models, this approach requires econometric modelling with appropriate specifications [21].

Thus, considering theoretical arguments and justifications based on the literature review, this study uses two approaches. First, Theil decomposition technique as Theil indices are additively decomposable into within and between sector components and it can be broadly used in understanding the main drivers of inequality. The other reason is that in contrast to the conventional inequality measure, Theil also satisfies all the required property of the inequality measure like Pigou-Dalton condition, anonymity principle, income and population homogeneity [16]. The Generalized Entropy measure (of which Theil is one of them) satisfies all of the axioms of scale independence, principle of population, anonymity, symmetry and decomposability [10].

Secondly, Blinder-Oaxaca decomposition is used for the second part of my analysis to examine contributions from different explanatory variables to the overall urban-rural expenditure disparity. This technique is often used to analyze outcome difference between two groups [22]. Thus, the first analysis explains the dynamic part while the second attempts to answer the sources of expenditure inequality.

\section{Theil decomposition}

To examine the expenditure inequality, the study decomposes by sub-groups like location (rural and urban), districts, gender, level of education and age of the household head. Gini coefficients fails the decomposability property and is seldom used [14]. However, Gini will be calculated to get the feel of how the overall inequality has changed over the period.

Consider that there are $\mathrm{N}$ households spread over in the rural and urban sector. Suppose ei is the per capita expenditure of rural household 1 , ej is the per capita expenditure of urban household $\mathrm{m}, \mu$ be the mean per capita expenditure of all the households, $\mathrm{Ni}$ and $\mathrm{Nj}$ be the number of households in rural sector $r$ and urban sector $u$ respectively. Suppose erl is the education level of household in rural sector and eum is the education level of household in urban sector. Thus, the overall expenditure inequality measured by the Gini is:

$$
\boldsymbol{G i n i}=\frac{1}{2 N^{2 \mu}} \sum_{r=1}^{2} \sum_{u=1}^{2} \sum_{l=1}^{n} \sum_{m=1}^{n}\left|\boldsymbol{e}_{r l}-\boldsymbol{e}_{u m}\right|
$$

The study also decomposes expenditure inequality by Theil indices by location. Theil Index T and $\mathrm{L}$ are estimated as [16]:

$$
T=\sum_{i} \sum_{j}\left(\frac{Y_{i j}}{y}\right) \log \left(\frac{Y_{i j} / y}{n_{i j} / n}\right)
$$

And

$$
L=\sum_{i} \sum_{j}\left(\frac{n_{i j}}{n}\right) \log \left(\frac{n_{i j} / n}{y_{i j} / y}\right)
$$

Where $y_{i j}$ is the total expenditure of households in $\mathrm{j}$ expenditure class in group $\mathrm{i}, \mathrm{y}$ is the total expenditure of all households, $\mathrm{n}_{\mathrm{ij}}$ is the number of households in $\mathrm{j}$ expenditure class in i group and $\mathrm{n}$ is the total number of all households.

From equation (2) \& (3), Theil $\mathrm{T}$ takes expenditure share as 
the weight while Theil $\mathrm{L}$ employs population share. Thus, Theil $\mathrm{T}$ is sensitive to upper expenditure change while Theil $\mathrm{L}$ is sensitive to lower expenditure change. However, both the indices can be decomposed into between and within sector components as follows [16]:

$$
T=\sum_{i} \sum_{j}\left(\frac{Y_{i j}}{y}\right) \log \left(\frac{Y_{i j}}{y}\right)=T_{w}+T_{b}
$$

And

$$
L=\sum_{i} \sum_{j}\left(\frac{n_{i j}}{n}\right) \log \left(\frac{n_{i j} / n}{y_{i j} / y}\right)
$$

\section{Blinder-Oaxaca decomposition}

To understand how the endowment differential, affect the expenditure disparity between urban and rural households, BlinderOaxaca decomposition is used. The model is specified as below:

$$
\mathrm{y}_{\mathrm{j}}=\beta_{\mathrm{j}} \mathrm{x}_{\mathrm{j}}+\mathrm{u}_{\mathrm{j}} ; \mathrm{E}\left(\mathrm{u}_{\mathrm{j}}\right)=0 \text { and } \mathrm{j}=\text { Urban \& Rural }
$$

where $y_{j}$ is natural log of per capita expenditure; $x_{j}$ is the vector of explanatory variables; $\beta_{j}$ is the coefficients of the explanatory variables; and $u_{j}$ is the error term.

Assume that the difference in the mean per capita expenditure between the urban and rural households as per two-fold decomposition be denoted by $\mathrm{D}$.

$$
\left.D=\overline{\boldsymbol{Y}_{u}}-\overline{\boldsymbol{Y}_{r}}=\overline{\left(\boldsymbol{Z}_{u}\right.}-\overline{\boldsymbol{Z}_{r}}\right)^{\prime} \hat{\boldsymbol{\beta}}+\left(\hat{\boldsymbol{\beta}}_{u}-\hat{\boldsymbol{\beta}}^{*}\right) \overline{\boldsymbol{Z}_{u}}{ }^{\prime}+\left(\hat{\boldsymbol{\beta}}^{*}-\hat{\boldsymbol{\beta}}_{r}\right) \overline{\boldsymbol{Z}_{r}}{ }^{\prime}
$$

Where:

$\hat{\beta}^{*}$ is the coefficient of the combined households;

$\hat{\boldsymbol{\beta}}_{r}$ is the coefficient of the rural households;

$\hat{\boldsymbol{\beta}}_{u}$ is the coefficient of the urban households; and

$\overline{Z_{\boldsymbol{k}}}$ is the estimate for $\mathrm{E} \overline{\boldsymbol{Z}_{\boldsymbol{k}}}$ obtained separately for urban and rural households.

The first term in equation (7) is the urban-rural difference in mean per capita expenditure explained by independent variables (endowment effect) while the remaining part of the equation is the unexplained part.

The explanatory variables included in the model are education, age, age square, gender, marital status and household size.

\section{Data}

Household level data are sourced from the two large scale household surveys BLSS 2007 and BLSS 2012 of the National Statistics Bureau. The BLSS 2007 covers a sample of 10,000 households while BLSS 2012 covers 8,968 households [23-24]. Both the surveys have adopted the Living Standard Measurement Survey (LSMS) of the World Bank as the methodology. Surveys were administered across twenty districts of Bhutan and cover extensive information on demography, education, health, employment, income, expenditure, housing conditions and assets of the households.

To carry out the decomposition analysis of expenditure inequality, key demographic indicators like household head sex, level of education, household size, household head gender, age, location, marital status, and household expenditure are considered.

The education of household head is sub-categorized into four as No Formal Education, Below Bachelor Degree, Bachelor Degree and Above Bachelor Degree. The household expenditure is broken down into Food and Non-Food. The household size is also categorized into different household sizes ranging from 1 to $10+$.

\section{Results and Discussion}

\section{Thiel decomposition results}

Table 1 presents the trend in the distribution of monthly household expenditures in 2007 and 2012 based on the Gini coefficients. The estimates of Gini coefficients in the table are based on the distribution of the per capita monthly household expenditure.

The Gini coefficient for food for the rural households has dropped by 3.3 percent in 2012 as compared to 2007 while non-food has increased by 0.4 percent giving the overall increase in the food expenditure inequality by 4.2 percent. The increase in inequality in rural households indicates that richer households have experienced faster growth in the consumption expenditure as compared to poorer households.

Conversely for the urban counterparts, the Gini coefficient for food fell by 1.4 percent while the non-food inequality fell sharply by 5.1 percent. The overall fall in the inequality in urban households was 1.4 percent. At the national level, food inequality dropped by 8.4 percent while non-food dropped by 9.2 percent which gave an aggregate fall in inequality by 6.1 percent in 2012 as compared to 2007 .

Table 2 presents the share of expenditure by quintiles. It was observed that the overall Gini coefficient was quite stable in 2007 and 2012. However, the urban component appeared to be decreasing. The proportion of the expenditure of the richest quintile to that of the poorest quintile was 15.2 in 2007, while in 2012 the ratio increased to 20.5. The data exhibits Simpson's Paradox that although the Gini coefficient has fallen from 0.424 in 2007 to 0.398 in 2012, in actual sense the proportion of the richest quintile to that of the poorest quintile has increased. Thus, interpreting inequality using the Gini coefficient alone

\begin{tabular}{|c|c|c|c|c|c|c|c|c|c|}
\hline \multirow[t]{2}{*}{ Location } & \multicolumn{3}{|l|}{2007} & \multicolumn{3}{|l|}{2012} & \multicolumn{3}{|c|}{$\%$ Change } \\
\hline & Food & Non-food & Total & Food & Non-food & Total & Food & Non-food & Total \\
\hline Rural & 0.3132 & 0.505 & 0.3727 & 0.3029 & 0.5068 & 0.3882 & $-3.30 \%$ & $0.40 \%$ & $4.20 \%$ \\
\hline Urban & 0.2989 & 0.4569 & 0.3638 & 0.2884 & 0.4338 & 0.3587 & $-3.50 \%$ & $-5.10 \%$ & $-1.40 \%$ \\
\hline All & 0.3343 & 0.5449 & 0.424 & 0.3063 & 0.4945 & 0.398 & $-8.40 \%$ & $-9.20 \%$ & $-6.10 \%$ \\
\hline
\end{tabular}
may not be reasonable.

Decomposition by the location of household: As observed, the

\begin{tabular}{|c|c|c|c|c|c|c|}
\hline \multirow[t]{2}{*}{ Year } & \multicolumn{5}{|c|}{ Quintiles } & \multirow{2}{*}{$\begin{array}{l}\text { Proportion of the richest quintile to the } \\
\text { poorest quintile }\end{array}$} \\
\hline & 1 & 2 & 3 & 4 & 5 & \\
\hline 2007 & 3.7 & 7.2 & 12.1 & 20.3 & 56.5 & 15.2 \\
\hline 2012 & 2.9 & 5.9 & 10.8 & 19.7 & 60.5 & 20.5 \\
\hline
\end{tabular}
mean monthly per capita expenditure for urban households is more

Table 1: Gini coefficients based on the per capita household expenditure.

Table 2: Share of expenditure (\% of total). 
than the rural households as shown in Tables 3 and 4 . The mean per capita household expenditure of urban households is almost twice or more as compared to the rural households.

In addition, the rural-urban expenditure disparity is quite large. In 2007, the between group accounted for almost 24 percent of the total inequality while its contribution is 12 percent of the total inequality in 2012 based on the Theil T index.

The rural inequality is larger than the urban inequality and it has increased from 37.3 percent in 2007 to 38.8 percent in 2012 . The story of inequality in Bhutan has been more of rural phenomenon and rural inequality has been the driving force for the overall expenditure inequality.

Decomposition by districts: Bhutan has a unique population distribution and economic activities. There are 20 districts. As per Table 5, between districts disparity in expenditure accounted for 21.5 percent as measured by Theil $\mathrm{T}$ in 2007 and 14.6 percent in 2012 . There is a decrease in the between districts disparity in expenditure by approximately seven percent.

However, the within district disparity in expenditure accounted for the major share of inequality. The story here is almost similar about urban-rural expenditure disparity as the percentage share of urban households differ from district to district.

Figure 1 shows the trends in Gini by 20 districts in Bhutan. Zhemgang district experienced the most reduction in the inequality. This indicates that most of the government policies to reduce poverty have been effective in this district. Zhemgang has been also identified as the most poverty reduced district on doing poverty assessment by the World Bank and National Statistics Bureau [5]. The 10th Five Year Plan (2008-2013) of the government which took the major initiative in constructing farm roads across the country in rural areas has immensely benefited the poor people in Zhemgang.

Similarly, Trongsa district has also experienced a reduction in inequality. The new installation of $720 \mathrm{MW}$ Mangdechhu hydro power project in 2010 may partly be accounted for the reduction as this project has helped the local economy to grow. The government's investment on electricity and communications have improved the connectivity and accessibility of the people. Farmers are now able to earn cash by selling vegetables to people working for hydro power projects. In fact, there are many hydro effects.

\begin{tabular}{|l|c|c|c|c|}
\hline \multirow{2}{*}{ Location } & \multicolumn{3}{|c|}{ Mean expenditure (Nu.) } & \multicolumn{2}{|c|}{ No. of households (\% Share) } \\
\cline { 2 - 5 } & $\mathbf{2 0 0 7}$ & $\mathbf{2 0 1 2}$ & $\mathbf{2 0 0 7}$ & $\mathbf{2 0 1 2}$ \\
\hline Rural & 2385.4 & 3835.2 & 70 & 48.5 \\
\hline Urban & 5379.6 & 6624 & 30 & 51.5 \\
\hline All & 3284.5 & 5271.6 & 100 & 100 \\
\hline Urban/Rural & 2.3 & 1.7 & & \\
\hline
\end{tabular}

Table 3: Mean per capita expenditure (monthly) for rural and urban households.

\begin{tabular}{|l|c|c|c|c|c|c|}
\hline \multirow{2}{*}{ Location } & \multicolumn{3}{|c|}{2007} & \multicolumn{3}{c|}{2012} \\
\cline { 2 - 7 } & Theil T & Theil L & Gini & Theil T & Theil L & Gini \\
\hline Rural & 0.2563 & 0.2287 & 0.3727 & 0.2841 & 0.2478 & 0.3882 \\
\hline Urban & 0.2472 & 0.2165 & 0.3638 & 0.24 & 0.211 & 0.3587 \\
\hline All group & 0.3319 & 0.3007 & 0.424 & 0.2911 & 0.2655 & 0.398 \\
\hline Within Group & 0.2518 & 0.2251 & & 0.2556 & 0.2289 & 0.4282 \\
\hline (\% share) & -75.9 & -74.8 & & -87.8 & -86.2 & \\
\hline Between Group & 0.0801 & 0.0756 & & 0.0356 & 0.0366 & 0.035 \\
\hline (\% share) & -24.1 & -25.2 & & -12.2 & -13.8 & \\
\hline
\end{tabular}

Table 4: Inequality decomposition by rural and urban households.

\begin{tabular}{|l|l|l|l|l|l|l|}
\hline District & $\mathbf{2 0 0 7}$ & \multicolumn{3}{l}{ 2012 } \\
\hline & Theil T & Theil L & Gini & Theil T & Theil L & Gini \\
\hline Bumthang & 0.2943 & 0.2421 & 0.3838 & 0.1477 & 0.1404 & 0.2938 \\
\hline Chhukha & 0.3203 & 0.2957 & 0.4213 & 0.251 & 0.2311 & 0.3733 \\
\hline Dagana & 0.1877 & 0.1832 & 0.332 & 0.1901 & 0.1774 & 0.3299 \\
\hline Gasa & 0.147 & 0.1373 & 0.2931 & 0.294 & 0.2711 & 0.4083 \\
\hline Haa & 0.1838 & 0.1778 & 0.3281 & 0.1495 & 0.1458 & 0.3016 \\
\hline Lhuentse & 0.2948 & 0.2387 & 0.3797 & 0.3342 & 0.3213 & 0.4382 \\
\hline Monggar & 0.2884 & 0.2509 & 0.3946 & 0.2868 & 0.2524 & 0.3913 \\
\hline Paro & 0.18 & 0.1716 & 0.3254 & 0.2583 & 0.2141 & 0.3603 \\
\hline Pema Gatshel & 0.1563 & 0.1468 & 0.2992 & 0.2635 & 0.177 & 0.321 \\
\hline Punakha & 0.2651 & 0.2396 & 0.3844 & 0.3034 & 0.265 & 0.3988 \\
\hline Samdrup & 0.3443 & 0.3127 & 0.4339 & 0.3861 & 0.3329 & 0.4487 \\
\hline Jongkhar & & & & & & \\
\hline Samtse & 0.2852 & 0.2554 & 0.3936 & 0.3438 & 0.266 & 0.4011 \\
\hline Sarpang & 0.1848 & 0.1749 & 0.3271 & 0.1734 & 0.158 & 0.3126 \\
\hline Thimphu & 0.2474 & 0.21 & 0.3567 & 0.2197 & 0.1866 & 0.3386 \\
\hline Trashigang & 0.238 & 0.2099 & 0.3588 & 0.2356 & 0.2183 & 0.3665 \\
\hline Trashi Yangtse & 0.2694 & 0.2088 & 0.3542 & 0.1855 & 0.1838 & 0.3366 \\
\hline Trongsa & 0.3579 & 0.3194 & 0.4385 & 0.2307 & 0.2347 & 0.3729 \\
\hline Tsirang & 0.2482 & 0.2183 & 0.3682 & 0.2647 & 0.2455 & 0.3899 \\
\hline Wangdue & 0.2727 & 0.2424 & 0.3864 & 0.2917 & 0.2524 & 0.3896 \\
\hline Phodrang & & & & & & \\
\hline Zhemgang & 0.5312 & 0.3958 & 0.4883 & 0.3041 & 0.2707 & 0.4029 \\
\hline All group & 0.3319 & 0.3007 & 0.424 & 0.2911 & 0.2655 & 0.398 \\
\hline Within Group & 0.2606 & 0.2332 & & 0.2487 & 0.2221 & \\
\hline (\% share) & -78.5 & -77.5 & & -85.4 & -83.7 & \\
\hline Between Group & 0.0714 & 0.0675 & & 0.0424 & 0.0434 & \\
\hline (\% share) & -21.5 & -22.5 & & -14.6 & -16.3 & \\
\hline & & & & & & \\
\hline
\end{tabular}

Table 5: Inequality decomposition by districts.

On the flip-side, inequality for Gasa district has increased. This is the district where most of the public infrastructures are still lacking. The most rural people in this district are deprived of health, education and access to road. The lower tail of the distribution in this district has further worsen as reflected in Figure 2.

Decomposition by the age of the household head: The income of the household tends to increase as the age of the household head increases. However, according to Akita et al. [16] this is happening only up to the certain level of age.

Table 6 shows the relation between the age of the household head and mean per capita monthly expenditure by location. The data reflects that as the household head gets older, the mean monthly household expenditure also increases and the fall in the expenditure is observed from the age bracket 25-29 years. Initially as the household head gets older, the size of the household also increases and from a certain age, there is a reduction in the size of the household. The other reasons are as children grow, they commence working and later become more independent. These are some of the reasons that can account for the positive correlation between the size of the household and expenditure.

The mean Urban/Rural expenditure ratio shows that the peak expenditure in urban area is almost 2.7 times that of rural households when the age of the household head is between 60 to 64 years in 2007 . However, the ratio has risen to 2 in 2012. Further, the mean household expenditure for urban households is almost 2.5 times that of rural households for the household head aged less than 19 years in 2007. However, this ratio has fallen to 0.95 in 2012 .

Table 7 presents inequality decomposition by age of the household head. The between sector component accounted for only 5-6.5 percent 
Citation: Tobden T (2017) Dynamics and Sources of Expenditure Inequality in Bhutan: Theil and Blinder Oaxaca Decomposition Analysis. Bus Eco J 8: 314. doi: 10.4172/2151-6219.1000314

Page 5 of 8

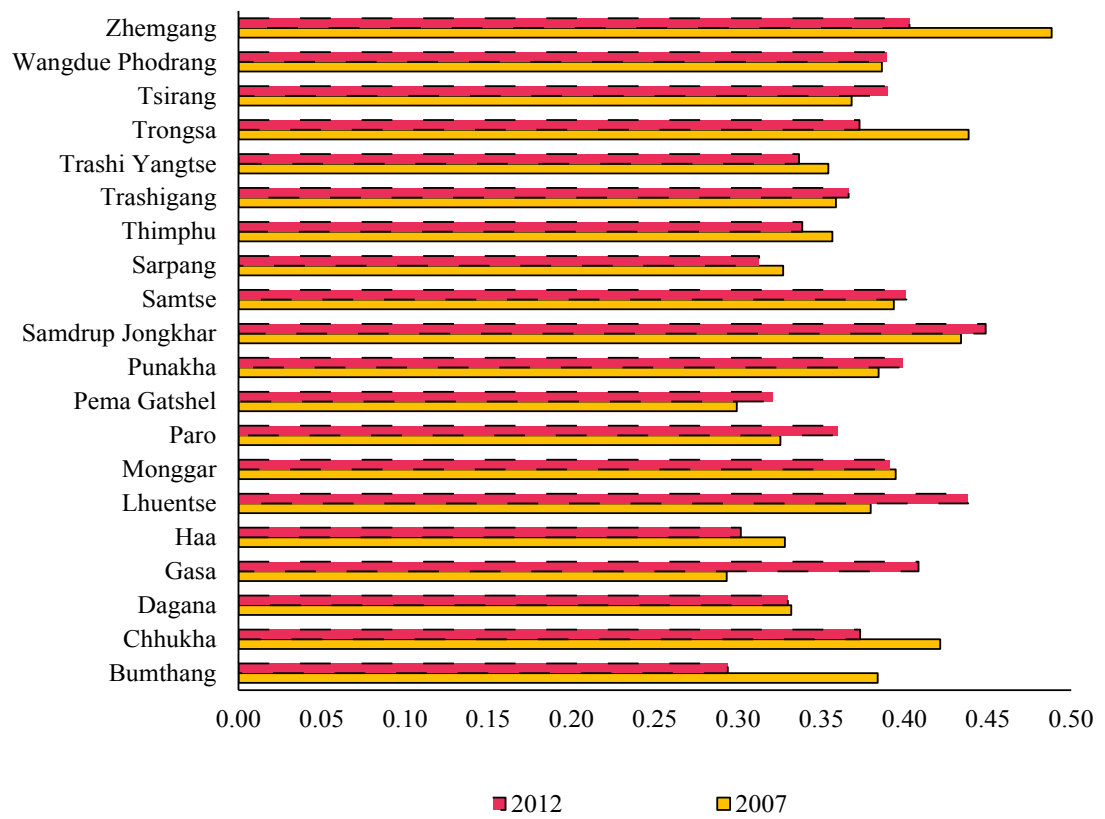

Figure 1: Trends in Gini coefficient by 20 districts.

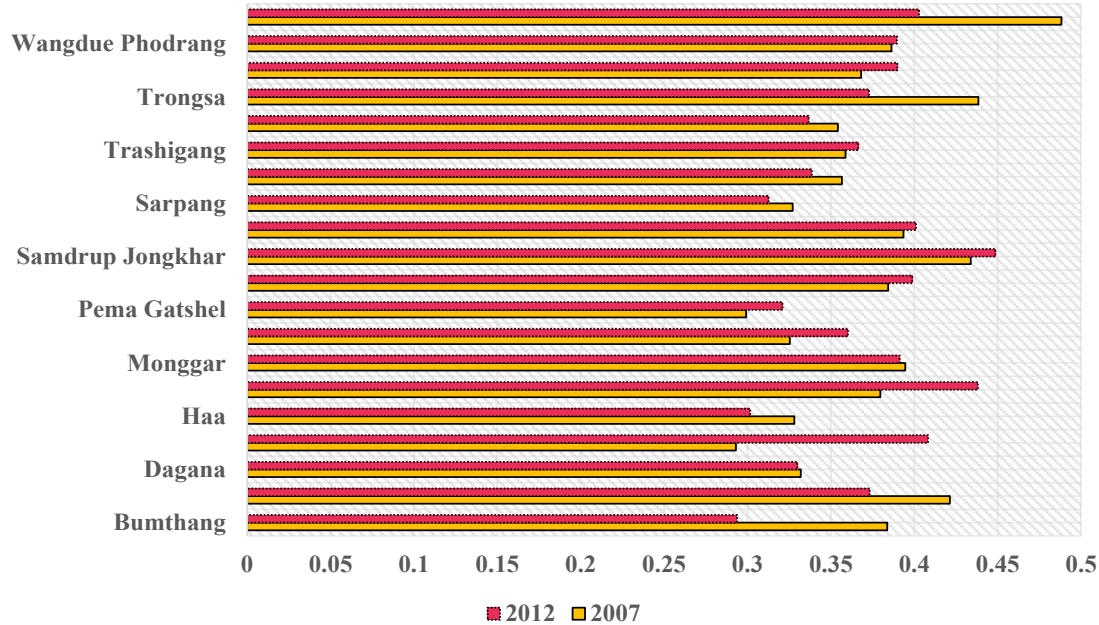

Figure 2: Estimates of Theil $L$ by 20 districts.

in 2007 and 4-4.5 percent of the total inequality in 2012 as measured in Theil indices. This indicates that expenditure disparity between age group was not statistically significant in the overall inequality. The within component was significant in the overall inequality and it accounted for the larger share of pie. In 2007, its contribution was approximately 94 percent while in 2012 , it has increased to 96 percent of the total inequality.

Decomposition by education: The education of the households in Bhutan can be categorized into four as No Education (formal), Below Bachelor's Degree, Bachelor's Degree and Above Bachelor's Degree. Education is also one of the major factors of income inequality. Education attainment and equal distribution of education is thought to generate more equal distribution of income [25].

Table 8 reflects the mean monthly household expenditure by the level of education. It was observed that the household head with the higher education attainment has larger mean monthly per capita expenditure. The mean expenditure tends to increase with the increase in the level of education. The mean expenditure for household head with education level Above Bachelor Degree was 3.4 times larger than households with No Formal Education in 2007, while it was only 2.8 times larger in 2012.

The mean Urban to Rural expenditure ratio shows that the mean expenditure for household with No Formal Education in urban areas was twice that of households with No Formal Education in rural areas in 2007. The ratios have been quite stable for rest of the education levels.

Theil decomposition by the level of education is provided in Table 9. The within group accounted for approximately 83 percent as measured in Theil indices in 2007 and 2012. This suggests that the overall inequality would have been much less had there been no disparity in household expenditure between the education level. 
Citation: Tobden T (2017) Dynamics and Sources of Expenditure Inequality in Bhutan: Theil and Blinder Oaxaca Decomposition Analysis. Bus Eco J 8: 314. doi: 10.4172/2151-6219.1000314

Page 6 of 8

\begin{tabular}{|l|c|c|c|c|c|c|}
\hline $\begin{array}{l}\text { Age } \\
\text { Group }\end{array}$ & $\begin{array}{c}\text { Mean } \\
\text { Expenditure } \\
\text { (Nu.) }\end{array}$ & $\begin{array}{c}\text { U/R ratio } \\
\text { (Mean } \\
\text { Expenditure) }\end{array}$ & & $\begin{array}{c}\text { Share of } \\
\text { Urban HH } \\
\text { (\%) }\end{array}$ & \\
\cline { 2 - 7 } & $\mathbf{2 0 0 7}$ & $\mathbf{2 0 1 2}$ & $\mathbf{2 0 0 7}$ & $\mathbf{2 0 1 2}$ & $\mathbf{2 0 0 7}$ & $\mathbf{2 0 1 2}$ \\
\hline$<=19$ & 2744.1 & 5657.6 & 2.48 & 0.95 & 3.77 & 0.32 \\
\hline $20-24$ & 4992.5 & 7061.1 & 1.13 & 1.12 & 0.51 & 6.26 \\
\hline $25-29$ & 4576.5 & 6673.8 & 1.94 & 1.43 & 8.26 & 19.2 \\
\hline $30-34$ & 4436.4 & 5567.8 & 1.85 & 1.55 & 20.02 & 18.1 \\
\hline $35-39$ & 3564.9 & 4961.9 & 2.28 & 1.55 & 17.37 & 15.8 \\
\hline $40-44$ & 3401.4 & 5041.2 & 2.16 & 1.77 & 17.51 & 12.21 \\
\hline $45-49$ & 3400.8 & 5272.4 & 2.45 & 1.93 & 11.56 & 10.67 \\
\hline $50-54$ & 3155.6 & 4997.7 & 2.19 & 1.96 & 8.6 & 6.9 \\
\hline $55-59$ & 2991.5 & 4707.6 & 2.15 & 1.78 & 7.75 & 4.2 \\
\hline $60-64$ & 2626.4 & 4230.4 & 2.72 & 1.91 & 2.28 & 2.3 \\
\hline $65+$ & 2327.8 & 4088 & 2.2 & 2 & 2.4 & 4 \\
\hline All group & 3284.5 & 5271.6 & 2.3 & 1.73 & 100 & 100 \\
\hline & & & & & & \\
\hline
\end{tabular}

Table 6: Mean monthly household expenditure by age.

\begin{tabular}{|l|l|l|l|l|l|l|}
\hline \multirow{2}{*}{ Age Group } & $\mathbf{2 0 0 7}$ & \multicolumn{3}{l}{$\mathbf{2 0 1 2}$} \\
\cline { 2 - 7 } & Theil T & Theil L & Gini & Theil T & Theil L & Gini \\
\hline$<=19$ & 0.3046 & 0.2748 & 0.4089 & 0.1282 & 0.1346 & 0.2864 \\
\hline $20-24$ & 0.3004 & 0.3035 & 0.4063 & 0.1762 & 0.1884 & 0.3296 \\
\hline $25-29$ & 0.3233 & 0.3083 & 0.422 & 0.2502 & 0.2375 & 0.3808 \\
\hline $30-34$ & 0.2937 & 0.2806 & 0.4078 & 0.2377 & 0.2149 & 0.3605 \\
\hline $35-39$ & 0.3097 & 0.2864 & 0.4089 & 0.2576 & 0.2264 & 0.3685 \\
\hline $40-44$ & 0.3283 & 0.2858 & 0.4116 & 0.3141 & 0.26 & 0.3909 \\
\hline $45-49$ & 0.3587 & 0.3082 & 0.4283 & 0.3368 & 0.2972 & 0.4214 \\
\hline $50-54$ & 0.3346 & 0.3005 & 0.4255 & 0.3355 & 0.297 & 0.4212 \\
\hline $55-59$ & 0.2952 & 0.2803 & 0.4121 & 0.3346 & 0.2867 & 0.4128 \\
\hline $60-64$ & 0.2929 & 0.2564 & 0.3943 & 0.2856 & 0.275 & 0.4065 \\
\hline $65+$ & 0.2735 & 0.2429 & 0.3847 & 0.2991 & 0.2674 & 0.4024 \\
\hline All group & 0.3319 & 0.3007 & 0.424 & 0.2911 & 0.2655 & 0.398 \\
\hline Within Group & 0.3131 & 0.282 & & 0.2792 & 0.2537 & \\
\hline (\% share) & -94.3 & -93.8 & & -95.9 & -95.6 & \\
\hline $\begin{array}{l}\text { Between } \\
\text { Group }\end{array}$ & 0.0188 & 0.0187 & & 0.012 & 0.0118 & \\
\hline (\% share) & -5.7 & -6.2 & & -4.1 & -4.4 & \\
\hline
\end{tabular}

Table 7: Inequality decomposition by age.

\begin{tabular}{|c|c|c|c|c|c|c|}
\hline \multirow[t]{2}{*}{ Education } & \multicolumn{2}{|c|}{$\begin{array}{l}\text { Mean } \\
\text { Expenditure (Nu.) }\end{array}$} & \multicolumn{2}{|c|}{$\begin{array}{l}\text { U/R ratio (Mean } \\
\text { Expenditure) }\end{array}$} & \multicolumn{2}{|c|}{$\begin{array}{l}\text { Share of Urban } \\
\mathrm{HH}(\%)\end{array}$} \\
\hline & 2007 & 2012 & 2007 & 2012 & 2007 & 2012 \\
\hline No Education & 2567.9 & 3936.9 & 2.1 & 1.5 & 35.04 & 31.6 \\
\hline $\begin{array}{l}\text { Below Bachelor } \\
\text { Degree }\end{array}$ & 4441.2 & 6133.8 & 1.7 & 1.3 & 56.49 & 56.6 \\
\hline Bachelor Degree & 7813.9 & 10035 & 1.2 & 1.3 & 3.43 & 8.8 \\
\hline $\begin{array}{l}\text { Above Bachelor } \\
\text { Degree }\end{array}$ & 8641.3 & 11077.3 & 1.5 & 1.8 & 5.03 & 3 \\
\hline All group & 3284.5 & 5271.6 & 2.3 & 1.7 & 100.0 & 100 \\
\hline
\end{tabular}

Table 8: Mean monthly household expenditure by the level of education.

Thus, focusing on education policy in raising the level of education would affect significantly on the reduction of overall inequality, treating all other factors as constant. The Gini coefficient for households with Above Bachelor Degree education has gone up from 32.5 percent in 2007 to 39.8 percent in 2012 while for the rest of the education level, inequality has fallen.

The Gini coefficient for household head with No Education has fallen from $38.79 \%$ in 2007 to $37.24 \%$ in 2012 . The Non-Formal Education (NFE) program provides basic literacy trainings to farmers in rural area and this appears to have bearing on the overall reduction

\begin{tabular}{|l|l|l|l|l|l|l|}
\hline Education & $\mathbf{2 0 0 7}$ & \multicolumn{7}{l|}{$\mathbf{2 0 1 2}$} \\
\hline & Theil T & Theil L & Gini & Theil T & Theil L & Gini \\
\hline $\begin{array}{l}\text { No Education } \\
\text { Below Bachelor } \\
\text { Degree }\end{array}$ & 0.2827 & 0.2492 & 0.3879 & 0.2534 & 0.229 & 0.3724 \\
\hline Bachelor Degree & 0.1938 & 0.2548 & 0.3896 & 0.2327 & 0.2084 & 0.3553 \\
\hline $\begin{array}{l}\text { Above Bachelor } \\
\text { Degree }\end{array}$ & 0.1768 & 0.1701 & 0.3248 & 0.3026 & 0.2537 & 0.3844 \\
\hline All group & 0.3319 & 0.3007 & 0.424 & 0.2911 & 0.2655 & 0.398 \\
\hline Within Group & 0.2734 & 0.2488 & & 0.241 & 0.219 & \\
\hline (\% share) & -82.4 & -82.7 & & -82.8 & -82.5 & \\
\hline Between Group & 0.0586 & 0.0519 & & 0.0501 & 0.0465 & \\
\hline (\% share) & -17.6 & -17.3 & & -17.2 & -17.5 & \\
\hline
\end{tabular}

Table 9: Inequality decomposition by the level of education.

\begin{tabular}{|l|c|c|c|c|c|c|}
\hline \multirow{2}{*}{ Gender } & \multicolumn{2}{|c|}{$\begin{array}{c}\text { Mean Expenditure } \\
\text { (Nu.) }\end{array}$} & \multicolumn{2}{|c|}{$\begin{array}{c}\text { U/R ratio (Mean } \\
\text { Expenditure) }\end{array}$} & \multicolumn{2}{|c|}{$\begin{array}{c}\text { Share of Urban HH } \\
\text { (\%) }\end{array}$} \\
\cline { 2 - 7 } & $\mathbf{2 0 0 7}$ & $\mathbf{2 0 1 2}$ & $\mathbf{2 0 0 7}$ & $\mathbf{2 0 1 2}$ & $\mathbf{2 0 0 7}$ & $\mathbf{2 0 1 2}$ \\
\hline Male & 3270.5 & 5217 & 2.3 & 1.7 & 78.4 & 80.4 \\
\hline Female & 3315.4 & 5420.1 & 2.3 & 1.8 & 21.6 & 19.6 \\
\hline All group & 3284.5 & 5271.6 & 2.3 & 1.7 & 100 & 100 \\
\hline
\end{tabular}

Table 10: Mean monthly household expenditure by gender.

in the inequality. The number of NFE centers have increased from five in 1992 to 953 in 2012 [26].

The Gini coefficient for household head with Below Bachelor Degree has also fallen from $38.96 \%$ in 2007 to $35.53 \%$ in 2012. This indicates that Continue Education (CE) program of the Ministry of Education which provides opportunities for in-service civil servants for qualification up gradation have been effective [27].

In all, the within group component has dropped from $27.34 \%$ in 2007 to $24.10 \%$ in 2012 as measured by Theil T. On the other spectra, the between group has remained stable.

Decomposition by gender: Table 10 presents the mean household expenditure by gender. The mean expenditure for Female headed household is more than the Male headed household. Data shows that Female headed households have lower education attainment while Male headed households have higher level of education. Further, the size of the household headed by females is more than the male headed households.

The inequality decomposition by gender of the household head is shown in Table 11 [28]. It indicates that the gender inequality does not exist as a problem as the between group accounted almost nothing of the total inequality. The within group accounted for almost 100 percent of the total inequality. Thus, focusing on the gender inequality would not have any positive impact on the overall inequality. The within inequality is more for the male headed households than the female headed households.

Decomposition by household size: Theil decomposition by household size (Table 12) shows that the larger the size of household, expenditure tend to increase. The per capita household expenditure falls as the household size increases. The per capita household expenditure with household size equal to 1 person was $\mathrm{Nu}$. 8,862 in 2007 while it was $\mathrm{Nu} .11,984.6$ in 2012 [29]. As the size of the household increases, the per capita expenditure fall, as observed in the case of $10+$ household size with $\mathrm{Nu}$. 1,546.5.

The disparity in expenditure by household size was observed quite large as reflected in Table 13. The between component accounted for 
Citation: Tobden T (2017) Dynamics and Sources of Expenditure Inequality in Bhutan: Theil and Blinder Oaxaca Decomposition Analysis. Bus Eco J 8: 314. doi: 10.4172/2151-6219.1000314

Page 7 of 8

\begin{tabular}{|l|l|l|l|l|l|l|}
\hline Age Group & $\mathbf{2 0 0 7}$ & \multicolumn{9}{l|}{$\mathbf{2 0 1 2}$} \\
\cline { 2 - 7 } & Theil T & Theil L & Gini & Theil T & Theil L & Gini \\
\hline Male & 0.344 & 0.3097 & 0.4296 & 0.2922 & 0.2642 & 0.3983 \\
\hline Female & 0.3055 & 0.2807 & 0.4114 & 0.2877 & 0.2683 & 0.3963 \\
\hline All group & 0.3319 & 0.3007 & 0.424 & 0.2911 & 0.2655 & 0.398 \\
\hline Within Group & 0.3319 & 0.3007 & & 0.291 & 0.2654 & \\
\hline (\% share) & -100 & -100 & & -100 & -99.9 & \\
\hline $\begin{array}{l}\text { Between } \\
\text { Group }\end{array}$ & 0.00002 & 0.00002 & & 0.0001 & 0.0001 & \\
\hline (\% share) & 0 & 0 & & 0 & -0.1 & \\
\hline
\end{tabular}

Table 11: Inequality decomposition by gender.

\begin{tabular}{|l|l|l|l|l|l|l|}
\hline $\begin{array}{l}\text { Size } \\
\text { (persons) }\end{array}$ & $\begin{array}{l}\text { Mean Expenditure } \\
\text { (Nu.) }\end{array}$ & \multicolumn{2}{l}{ U/R ratio } & \multicolumn{3}{l|}{$\begin{array}{l}\text { Share of Urban HH } \\
\text { (\%) }\end{array}$} \\
\cline { 2 - 7 } & $\mathbf{2 0 0 7}$ & $\mathbf{2 0 1 2}$ & $\mathbf{2 0 0 7}$ & $\mathbf{2 0 1 2}$ & $\mathbf{2 0 0 7}$ & $\mathbf{2 0 1 2}$ \\
\hline 1 & 8862 & 11984.6 & 2 & 1.5 & 6.08 & 6.45 \\
\hline 2 & 4903.6 & 7430.1 & 2.1 & 1.6 & 9.72 & 10.37 \\
\hline 3 & 3854 & 6304.5 & 1.9 & 1.7 & 15.67 & 17.93 \\
\hline 4 & 3414.2 & 4932.2 & 1.9 & 1.5 & 23.79 & 24.33 \\
\hline 5 & 2903.2 & 4348.4 & 2.1 & 1.6 & 18.97 & 21.78 \\
\hline 6 & 2533.4 & 3590.8 & 2.1 & 1.7 & 13.49 & 11.17 \\
\hline 7 & 2162.9 & 3231.5 & 2.2 & 1.8 & 6.63 & 4.78 \\
\hline 8 & 2083.3 & 3171.4 & 2.3 & 2.1 & 3.16 & 2.01 \\
\hline 9 & 1964.7 & 2926.9 & 2.8 & 2.2 & 1.33 & 0.91 \\
\hline $10+$ & 1546.5 & 1928.9 & 3 & 2.1 & 1.16 & 0.26 \\
\hline All group & 3284.5 & 5271.6 & 2.3 & 1.7 & 100 & 100 \\
\hline & & & & & & \\
\hline
\end{tabular}

Table 12: Mean monthly household expenditure by household size.

\begin{tabular}{|l|l|l|l|l|l|l|}
\hline Size (persons) & $\mathbf{2 0 0 7}$ & \multicolumn{5}{l|}{$\mathbf{2 0 1 2}$} \\
\cline { 2 - 7 } & Theil T & Theil L & Gini & Theil T & Theil L & Gini \\
\hline 1 & 0.2572 & 0.2701 & 0.3836 & 0.18255 & 0.1882 & 0.32679 \\
\hline 2 & 0.2888 & 0.2499 & 0.3848 & 0.21944 & 0.2095 & 0.35087 \\
\hline 3 & 0.2381 & 0.2201 & 0.364 & 0.27813 & 0.2283 & 0.36789 \\
\hline 4 & 0.2225 & 0.2122 & 0.3581 & 0.20016 & 0.1818 & 0.33029 \\
\hline 5 & 0.2767 & 0.2354 & 0.3769 & 0.20331 & 0.1845 & 0.33412 \\
\hline 6 & 0.234 & 0.2194 & 0.3649 & 0.20283 & 0.189 & 0.34092 \\
\hline 7 & 0.2449 & 0.2259 & 0.3725 & 0.20453 & 0.1889 & 0.34054 \\
\hline 8 & 0.2994 & 0.2567 & 0.3961 & 0.36489 & 0.2976 & 0.4269 \\
\hline 9 & 0.3014 & 0.2677 & 0.4068 & 0.35018 & 0.2828 & 0.41387 \\
\hline $10+$ & 0.2774 & 0.2356 & 0.38 & 0.18127 & 0.172 & 0.32691 \\
\hline All group & 0.3319 & 0.3007 & 0.424 & 0.2911 & 0.2655 & 0.398 \\
\hline Within Group & 0.2537 & 0.2306 & & 0.2223 & 0.2007 & \\
\hline (\% share) & -76.4 & -76.7 & & -76.4 & -75.6 & \\
\hline Between & 0.0782 & 0.0701 & & 0.0688 & 0.0648 & \\
\hline Group & & & & & & \\
\hline \% share) & -23.6 & -23.3 & & -23.6 & -24.4 & \\
\hline
\end{tabular}

Table 13: Decomposition by household size

almost 23-24 percent of the total inequality in 2007 and 2012 when measured in Theil indices.

\section{Blinder-Oaxaca decomposition results}

Blinder Oaxaca Decomposition Results are presented in Table 14. The education endowment differential between rural and urban households appears to have significant impact on urban-rural expenditure disparity. The education accounts for 27 percent of the difference in urban-rural expenditure in 2007 while its contribution increased to 29 percent in 2012. There are other factors (unexplained part) which account for 65 percent and 66 percent of the total difference in mean expenditure in 2007 and 2012 respectively. Thus, reducing the difference in the education attainment between rural and urban households is critical.

\begin{tabular}{|c|c|c|c|c|c|c|}
\hline \multirow[t]{2}{*}{$\ln (P C E)$} & \multicolumn{3}{|l|}{2007} & \multicolumn{3}{|l|}{2012} \\
\hline & b/se & Z-Value & $\begin{array}{l}\% \\
\text { Contribution }\end{array}$ & b/se & Z-Value & $\begin{array}{l}\% \\
\text { Contribution }\end{array}$ \\
\hline \multicolumn{7}{|c|}{ Differential } \\
\hline \multirow{2}{*}{$\begin{array}{l}\text { Prediction } \\
\text { for Urban }\end{array}$} & $8.451^{\star \star \star}$ & \multirow[t]{2}{*}{598.35} & \multirow{6}{*}{100} & $8.587^{\star \star \star}$ & \multirow[t]{2}{*}{953.2} & \multirow{6}{*}{100} \\
\hline & $(0.014)$ & & & $(0.009)$ & & \\
\hline \multirow{2}{*}{$\begin{array}{l}\text { Prediction } \\
\text { for Rural }\end{array}$} & $7.833^{\star \star \star}$ & \multirow[t]{2}{*}{402.12} & & $8.004^{* * *}$ & \multirow[t]{2}{*}{798.99} & \\
\hline & (0.019) & & & $(0.01)$ & & \\
\hline \multirow[t]{2}{*}{ Difference } & $0.618^{\star \star \star}$ & \multirow[t]{2}{*}{25.71} & & $0.583^{\star * *}$ & \multirow[t]{2}{*}{43.29} & \\
\hline & $(0.024)$ & & & $(0.013)$ & & \\
\hline \multicolumn{7}{|l|}{ Explained } \\
\hline \multirow[t]{2}{*}{ Education } & 0.169 & \multirow[t]{2}{*}{15.42} & \multirow[t]{2}{*}{27.35} & $0.169^{\star * \star}$ & \multirow[t]{2}{*}{23.56} & \multirow[t]{2}{*}{28.99} \\
\hline & $(0.011)$ & & & $(0.007)$ & & \\
\hline \multirow[t]{2}{*}{ Age } & $(-0.144)^{\star \star \star}$ & \multirow[t]{2}{*}{-5.49} & \multirow[t]{2}{*}{-23.3} & $(-0.192)^{\star \star *}$ & \multirow[t]{2}{*}{-7.74} & \multirow[t]{2}{*}{-32.93} \\
\hline & $(0.026)$ & & & $(0.025)$ & & \\
\hline \multirow{2}{*}{$\begin{array}{l}\text { Age } \\
\text { Square }\end{array}$} & $0.126^{\star \star \star}$ & \multirow[t]{2}{*}{4.94} & \multirow[t]{2}{*}{20.39} & $0.153^{* * *}$ & \multirow[t]{2}{*}{6.5} & \multirow[t]{2}{*}{26.24} \\
\hline & (0.026) & & & $(0.024)$ & & \\
\hline \multirow[t]{2}{*}{ Gender } & $0.0004^{\star \star *}$ & 0.1 & 0.06 & $(-0.024)^{* * *}$ & 6.5 & -4.12 \\
\hline & $(0.004)$ & & & $(0.002)$ & & \\
\hline hh size & $0.069^{\star \star \star}$ & 6.63 & 11.17 & $0.085^{\star \star \star}$ & 13.57 & 14.58 \\
\hline & $(0.01)$ & & & $(0.006)$ & & \\
\hline Marital & $(-0.001)$ & -0.76 & -0.16 & $0.008^{\star \star \star}$ & 5.51 & 1.37 \\
\hline & $(0.001)$ & & & $(0.002)$ & & \\
\hline Total & $0.219^{\star \star \star}$ & 13.57 & 35.44 & $0.200^{\star * \star}$ & 20.29 & 34.31 \\
\hline & $(0.016)$ & & & $(0.01)$ & & \\
\hline Unexplain & ed & & & & & \\
\hline Total & $0.399^{\star \star \star}$ & 19.49 & 64.56 & $0.384^{\star \star *}$ & 29.06 & 65.87 \\
\hline & $(0.020)$ & & & $(0.013)$ & & \\
\hline
\end{tabular}

Table 14: Blinder-Oaxaca decomposition by location of household in mean per capita expenditure.

\section{Conclusion and Policy Implications}

Inequality has been one of the immerging policy issues in Bhutan. The real GDP growth has been continuously growing at the average rate of 4 percent per annum. The expenditure inequality as measured in Gini based on per capita expenditure has also fallen with $6.1 \%$ in 2012 as compared to 2007. Bhutan was successful in eradicating poverty by almost half in 2012 from 23.2 percent in 2007 (National Statistics Bureau 2012c).

This study analyses the dynamic of expenditure inequality and what were some of the potential sources. The Theil decomposition and Blinder-Oaxaca decomposition analysis using the Bhutan Living Standard Survey data of 2007 and 2012 revealed that between dzongkhags (districts) accounted for 21-23 percent of the total inequality in 2007. The between districts didn't matter much in 2012 as its contribution to the total inequality was $14-17$ percent. Thus, the policymakers of Bhutan should focus more on within districts rather than between districts to have small national inequality. The between urban-rural expenditure inequality accounted for 14-24 percent of the total inequality for which the government should give utmost priority.

Education also came out as the important determining factor for the overall expenditure inequality. The between component accounted for 17-18 percent of the total inequality in 2007 and 2012. The mean expenditure for household heads with Bachelor Degree is 3 times more than household heads with No Formal Education and 2 times that of 
Citation: Tobden T (2017) Dynamics and Sources of Expenditure Inequality in Bhutan: Theil and Blinder Oaxaca Decomposition Analysis. Bus Eco J 8: 314. doi: 10.4172/2151-6219.1000314

Page 8 of 8

household heads with Below Bachelor Degree. Thus, education has significant bearing on the overall reduction of the inequality.

The inequality by gender was not significant as the between component did not account anything of the total inequality. Therefore, the government's intervention on reducing inequality in gender would not have significant impact on the overall inequality reduction. Similarly, the age of the household head was also not so significant as the between inequality barely accounted for 5-6.5 percent of the total inequality. The within inequality accounted for the larger share of inequality and it increases with the age of the household head.

The disparity in the expenditure was observed significant when the household size is considered. The between inequality accounted for 23-24.5 percent of the total inequality. As the size of the household increases, the expenditure also increases but the per capita expenditure falls. Thus, the focus of the policy intervention should be more on within inequality rather than the between inequality to achieve smaller national inequality.

The per capita expenditure used in the analysis are all in current prices. So, this study has limitation. To make the data comparable across the board, using constant prices make more sense. The cost of living in urban and rural areas are different and it is true for different districts in the country. So, adjustment in the cost of living has not be made in lieu of limited information. Thus, the expenditure inequality calculated here may be overestimated and this leaves room for future research.

\section{Acknowledgement}

I would like to express my sincere thanks to Dr. Hoa Nguyen, Crawford Schoo of Public Policy, the Australian National University for her supervision and valuable suggestions for the paper. Her guidance on the paper immensely benefited. My heartfelt thanks also go to Dr. Syed Hassan, Crawford School of Public Policy for rendering additional support for improving the paper. Professor Chris Adams, the academic advisor for Crawford School of Public Policy also needs my specia mention for helping me with the overall structuring of the paper.

\section{References}

1. RGoB (2008) The Constitution of The Kingdom of Bhutan, p: 18.

2. UNDP (2005) Poverty Outcome Evaluation.

3. Gross National Happiness Commission (2016).

4. IMF (2004) Bhutan: Poverty Reduction Strategy Paper.

5. National Statistics Bureau (2014) Bhutan Poverty Assessment 2014

6. National Statistics Bureau (2016) National Accounts Statistics 2016

7. National Statistics Bureau (2012c) Bhutan Poverty Analysis 2012.

8. Litchfield JA (1999) Inequality: methods and tools.
9. National Statistics Bureau (2012b) Multidimensional Poverty Index.

10. Cowell FA, Jenkins SP (1995) How much inequality can we explain? A methodology and an application to the United States. The Economic Journal, pp: 421-430.

11. Cowell FA (1988) Inequality decomposition: three bad measures. Bulletin of Economic Research 40: 309-312.

12. Shorrocks AF (1982) Inequality Decomposition by Factor Components. Econometrica 50: 193-211.

13. Asra A (2000) Poverty And Inequality In Indonesia: Estimates, Decomposition And Key Issues. Journal of the Asia Pacific Economy 5: 91.

14. Bourguignon F (1979) Decomposable income inequality measures Econometrica: Journal of the Econometric Society, pp: 901-920.

15. Foster JE, Shneyerov AA (1999) A general class of additively decomposable inequality measures. Economic Theory 14: 89-111.

16. Akita T, Lukman RA, Yamada $Y$ (1999) Inequality in the Distribution of Household Expenditures in Indonesia: A Theil Decomposition Analysis. The Developing Economies 37: 197-221.

17. Hayashi M, Kataoka M, Akita T (2014) Expenditure Inequality in Indonesia 2008-2010: A Spatial Decomposition Analysis and the Role of Education. Asian Economic Journal 28: 389-411.

18. Brewer M, Wren-Lewis $L$ (2016) Accounting for Changes in Income Inequality: Decomposition Analyses for the UK, 1978-2008. Oxford Bulletin of Economics and Statistics 78: 289-322.

19. Cain JS, Hasan R, Magsombol R, Tandon A (2010) Accounting for Inequality in India: Evidence from Household Expenditures. World Development 38: 282297.

20. Morduch J, Sicular T (2002) Rethinking inequality decomposition, with evidence from rural China. The Economic Journal 112: 93-106.

21. Cowell FA, Fiorio CV (2011) Inequality decompositions-a reconciliation. The Journal of Economic Inequality 9: 509-528.

22. Jann B (2008) The Blinder-Oaxaca decomposition for linear regression models The Stata Journal 8: 453-479.

23. National Statistics Bureau (2007) Bhutan Living Standard Survey 2007 Report.

24. National Statistics Bureau (2012a) Bhutan Living Standards Survey 2012 Report.

25. Gregorio JD, Lee JW (2002) Education and Income Inequality: New Evidence from Cross-Country Data. Review of Income and Wealth 48: 395-416.

26. BBS (2012) Bhutan receives US $\$ 20,000$ for NFE Programme. Bhutan Broad Casting Service.

27. Gross National Happiness Commission (1999).

28. World Bank (2016) Measuring Living Standards: Household Consumption and Wealth Indices.

29. Haughton J, Khandker SR (2009) Handbook on Poverty and Inequality. World Bank Publications. 